\title{
PERBANDINGAN TEKNIK HOMOGENISASI DARAH EDTA DENGAN TEKNIK INVERSI DAN TEKNIK ANGKA DELAPAN TERHADAP JUMLAH TROMBOSIT
}

\author{
Hartina $^{I^{*}}$, Ardiya Garini, M.Ihsan Tarmizi \\ *Jurusan Analis Kesehatan Poltekkes Kemenkes Palembang \\ E-mail: ardiya1980@gmail.com
}

Diterima: 26 Desember 2018

Direvisi: 10 Januari 2019

Disetujui:24Januari 2019

\begin{abstract}
Abstrak
Tahapan pra analitik sangat penting untuk mendapatkan hasil pemeriksaan yang akurat. Spesimen yang tidak dihomogenkan dengan baik dapat mempengaruhi hasil pemeriksaan jumlah sel dalam darah khususnya darah yang menggunakan antikoagulan EDTA. Menurut Decie and Lewis, homogenisasi dilakukan menggunakan teknik inversi dengan membolak-balikkan tabung 8 sampai 10 kali. Namun teknik inversi ini tidak semuanya dilakukan oleh ATLM, sebagian ATLM menggunakan teknik homogenisasi dengan membentuk angka delapan. Tidak segera mencampur darah dengan antikoagulan atau pencampuran yang kurang adekuat dapat menyebabkan agresi trombosit, bahkan dapat terjadi bekuan. Penelitian ini bertujuan untuk mengetahui ada tidaknya perbedaan jumlah trombosit pada darah yang dihomogenkan dengan teknik inversi dan teknik angka delapan menggunakan Automatic Hematology Analyzer Sysmex KX-21. Jenis penelitian ini merupakan penelitian analitik dengan pendekatan cross sectional. Penelitian dilakukan di Balai Besar Laboratotium Kesehatan Palembang pada bulan Maret-Juni 2018. Sampel diambil dari pasien yang melakukan pemeriksaan darah lengkap di Balai Besar Laboratorium Kesehatan sebanyak 33 responden. Dari analisis uji statistik parametrik $t$ paired sample test didapat nilai $\mathrm{p}=0,001$ artinya yang signifikan pada jumlah trombosit darah EDTA yang dihomogenkan dengan teknik inversi dan teknik angka delapan. Disarankan pada ATLM sebaiknya darah EDTA dihomogenkan dengan teknik inversi agar didapatkan hasil yang akurat.
\end{abstract}

Kata Kunci: Jumlah trombosit; darah EDTA; teknik homogenisasi

\begin{abstract}
Pre-analytical phase is very important in order to obtain accurate results. If the specimen is not homogenized well, it can affect the results of blood count in specimens especially added with EDTA as anticoagulant. According to Decie and Lewis, homogenization should be done using inversion technique by turning the tubes upside down for 8-10 times. However, not all of medical laboratory technologists do this technique. Some of them homogenize the specimens by moving tubes forming number-eight movement. Delay in mixing the blood with anticoagulants or mixing with less anticoagulant can cause aggression and even clot formation. The aim of this study was to know the difference of platelet count in blood with EDTA as anticoagulant between inversion technique and number-eight technique. The samples were measured using Automatic Hematology Analyzer Sysmex KX-21.This was analytical study with cross sectional approach conducted at Balai Besar Laboratorium Kesehatan Palembang from March to June 2018. The samples were 33 patients examining complete blood count. From paired t-test, the result showed $p$ value was 0.001 less than $\alpha(0.05)$. It meant there was a significant difference in the number of platelet counts between blood homogenized using inversion techniques and number-eight technique. For medical laboratory technologists, it is preferably to homogenize EDTAanticoagulated blood using inversion technique to obtain accurate results.
\end{abstract}

Keywords: platelets count; EDTA-anticoagulated blood; homogenization technique

\section{PENDAHULUAN}

Trombosit merupakan salah satu keping darah yang juga terbentuk di sumsum tulang merah dari bahan pluripotential stem cell. Trombosit berperan dalam sistem penjendalan/pengumpulan darah, karena mengandung bahan-bahan berupa protein yang berupa fibrinogen. Reaksi mendasar penggumpalan darah diawali dengan konversi protein plasma fibrinogen menjadi fibrin yang tidak larut (Tri,2014). 
Hasil yang akurat pada pemeriksaan laboratorium dapat dicapai apabila memperhatikan tahapan-tahapan pra analitik, analitik, dan pasca analitik. Ketigatahapan ini sangat penting karena berhubungan satu dengan yang lain, salah satu hal yang penting dalam tahap pra analitik adalah saat homogenisasi spesimen. Spesimen yang tidak dihomogenkan dengan baik dapatmempengaruhi hasil pemeriksaan jumlah trombosit ( Gandasoebrata, 2010),

Penghomogenan darah harus dilakukan dengan segera. Penghomogenan darah dilakukan sesuai dengan gold standar, Menurut Decie andLewis, cara yang dilakukan untuk menghomogenkan darah yaitu menggunakan teknik inversi dengan membolak-balikkan tabung 8 sampai 10 kali. Jika homogenisasi tidak dilakukan akan menyebabkan koagulasi sehingga akan mengganggu pemeriksaan jumlah trombosit (Deciedan Lewis, 1991; Katharyn, dkk 2008).

Namun teknik inversi ini tidak semuanya dilakukan oleh ATLM, 70-90\% ATLM menggunakan teknik homogenisasi dengan membentuk angka delapan (Tettydkk, 2017). Pada pelatihan hematologi teknik homogenisasi yang diajarkan adalah teknik angka delapan. Namun sejauh ini belum diketahui apakah ada atau tidak perbedaan cara homogenisasi tersebut terhadap jumlah trombosit. Penelitian ini bertujuan untuk mengetahui apakah ada perbedaan teknik homogenisasi darah EDTA dengan teknik inversi dan teknik angka delapan terhadap jumlah trombosit.

\section{METODE PENELITIAN}

Penelitian ini bersifat analitik dengan pendekatan cross sectional dimana variabel dependen dan independen dilakukan secara bersamaan. Pengambilan data untuk penelitian dilakukan di Balai Besar Laboratorium Kesehatan Palembang dalam peiode bulan Maret-Juni 2018. Populasi penelitian adalah seluruh pasien yang melakukan pemeriksaan darah lengkap di Balai Besar Laboratorium Kesehatan Palembang. Sampel pada penelitian ini diambil dari darah vena pasien yang melakukan pemeriksaan darah lengkap yang memenuhi kriteria peneliti sebanyak 30 sampel berdasarkan distribusi student ${ }^{(6)}$. Adapun kriteria tersebut adalah pasien usia 20-50 tahun baik laki-laki maupun perempuan dan hasil hitung jumlah trombosit normal. Alat yang digunakan untuk penelitian ini adalah Automatic Hematology Analizer sysmex $K X-21$.

\section{HASIL DAN PEMBAHASAAN HASIL}

Tabel 1Distribusi Statistik Deskriftif Hasil Hitung Jumlah Trombosit yang Dihomogenkan dengan Teknik Inversi

\begin{tabular}{|c|c|c|c|c|c|}
\hline Variabel & N & $\begin{array}{c}\text { Mean } \\
\text { Median }\end{array}$ & SD & $\begin{array}{c}\text { Min } \\
\text { Mak }\end{array}$ & $\begin{array}{c}\mathbf{9 5 \%} \\
\text { Cl }\end{array}$ \\
\hline $\begin{array}{c}\text { Jumlah Trombosit } \\
\text { yang dihomogenkan }\end{array}$ & 33 & 284 & 69 & 143 & 259 \\
dengan Teknik & & 285 & & 447 & - \\
$\begin{array}{c}\text { Inversi } \\
(\times 10 \% \mu \text { Darah })\end{array}$ & & & & & 308 \\
\hline
\end{tabular}

Berdasarkan data pada tabel 1 hasil analisis deskriftif hitung jumlah trombosit dari 33 sampel darah EDTA yang dihomogenkan dengan teknik inversi, didapat bahwa rata-rata jumlah trombosit $284.10^{3} / \mu$ darah dengan jumlah minimum $143.10^{3} / \mu$ l darah dan jumlah maksimum $447.10^{3} / \mu 1$ darah serta standar devisiasi sebesar $69.10^{3} / \mu$ d darah. Dari hasil estimasi interval dapat disimpulkan bahwa 95\% diyakini bahwa rata-rata jumlah trombosit adalah diantara $259.10^{3} / \mu 1$ darah sampai dengan $308.10^{3} / \mu 1$ darah. 
Tabel 2.Distribusi Statistik Deskriftif Hasil Hitung Jumlah Trombosit yang Dihomogenkan dengan Teknik Angka Delapan

\begin{tabular}{c|c|c|c|c|c}
\hline Variabel & N & $\begin{array}{c}\text { Mean } \\
\text { Median }\end{array}$ & SD & $\begin{array}{c}\text { Min } \\
\text { Maks }\end{array}$ & $\begin{array}{c}\mathbf{9 5 \%} \\
\text { Cl }\end{array}$ \\
\hline $\begin{array}{c}\text { Jumlah } \\
\text { Trombosit yang } \\
\text { dihomogenkan }\end{array}$ & 33 & 276 & 67 & 146 & 252 \\
dengan Teknik & & 279 & & 447 & - \\
Angka Delapan & & & & & 299 \\
$\left(\mathrm{x} 10^{3} / \mu\right.$ Darah $)$ & & & & & \\
\hline
\end{tabular}

Berdasarkan tabel 2 hasil analisis deskriftif hitung jumlah trombosit dari 33 sampel darah EDTA yang dihomogenkan dengan teknik angka delapan, dapat dilihat bahwa rata-rata jumlah trombosit $276.10^{3} / \mu 1$ darah, denganjumlah minimum $146.10^{3} / \mu 1$ darah danjumlah maksimum $447.10^{3} / \mu 1$ darah serta standar deviasi sebesar $67.10^{3} / \mu$ d darah. Dari hasil estimasi interval dapat disimpulkan bahwa 95\% diyakini rata-rata jumlah trombosit adalah diantara $252.10^{3} / \mu$ l darah sampai dengan $299.10^{3} / \mu 1$ darah.

Data hasil penelitian yang sudah dianalisis secara statistik deskriftif kemudian dilakukan uji normalitas dengan menggunakan uji One-Sample Kolmogorov Smirnov.Didapat hasil sampel darah EDTA yang dihomogenkan dengan teknik inversi adalah 0,200 dan dengan teknik angka delapan adalah 0,200. Kedua kelompok menunjukkan nilai $\mathrm{P}>0,05$ dan dapat disimpulkan bahwa kedua kelompok data berdistribusi normal sehingga data dapat dianalisis dengan t-paired sample test.

Tabel 3Perbedaan Hasil Pemeriksaan Hitung Jumlah Trombosit antara Darah EDTA yang dihomogenkan dengan Teknik Inversi dan Teknik Angka Delapan

\begin{tabular}{c|c|c|c|c|c}
\hline Variabel & N & Mean & $\begin{array}{c}\text { Min } \\
\text { Mak }\end{array}$ & SD & $\begin{array}{c}\text { P } \\
\text { Value }\end{array}$ \\
\hline Teknik Inversi & 33 & 284 & 143 & 69 & 0,001 \\
$\left(\mathrm{x} 10^{3} / \mu\right.$ l Darah $)$ & & & 447 & & \\
\hline
\end{tabular}

\begin{tabular}{c|c|c|c|c|c}
\hline $\begin{array}{c}\text { Teknik Angka } \\
\text { Delapan } \\
\left(\mathrm{x} 10^{3} / \mu \mathrm{l} \text { Darah }\right)\end{array}$ & 33 & 276 & 146 & 67 & 0,001 \\
& & & 447 & & \\
\hline
\end{tabular}

Berdasarkan hasil uji t-paired test didapatkan nilai $\mathrm{p}=0,001$ artinya $p$ value $<$ $\alpha(0,05)$. Keputusan statistik yang diambil yaitu Ho ditolak. Dapat disimpulkan bahwa pada alpha 5\%, ada perbedaan yang signifikan antara jumlah trombosit pada sampel darah EDTA yang dihomogenkan dengan teknik inversi dan teknik angka delapan.

\section{PEMBAHASAN}

Dari hasil penelitian didapatkan nilai rata-rata jumlah trombosit yang dihomogenkan dengan teknik inversi lebih besar, yaitu $284.10^{3} / \mu 1$ darah dibandingan dengan yang dihomogenkan dengan teknik angka delapan, yaitu $276.10^{3} / \mu 1$ darah. Selisih nilai rata-rata jumlah trombosit sebanyak $8.10^{3} / \mu$ darah, selisih nilai ratarata ini kelihatannya kecil. Tetapi dari hasil uji $t$ paired sampel test didapatkan nilaip value sebesar 0,001 yang berarti lebih kecil dari nilai alpha 0,05 yang menunjukkan ada perbedaan hasil jumlah trombosit antara darah EDTA yang dihomogenkan dengan teknik inversi dan teknik angka delapan. Hal ini dapat terjadi karena adanya perbedaan kecepatan homogenisasi antara teknik inversi dan teknik angka delapan. Homogenisasi dengan teknik inversi mempunyai waktu yang lebih cepat dibandingkan dengan teknik angka delapan. Menurut Decie and Lewis, homogenisasi dilakukan menggunakan teknik inversi dengan membolak-balikkan tabung sebanyak 8 sampai 10 kali(Decie and Lewis 1991).Perbedaan

kecepatan penghomogenan ini kemungkinan menyebabkan perbedaan jumlah trombosit. Apabila homogenisasi sampel darah 
dengan antikoagulan atau pencampuran yang kurang adekuat juga dapat menyebabkan agregasi trombosit bahkan dapat terjadi bekuan(Gandasoebrata, 2010). sehingga pada alat hematology analyzer tidak terbaca sebagai sel trombosit. Hasil penelitian ini sesuai dengan gold standar.

\section{KESIMPULAN}

Rata-rata jumlah trombosit yang dihomogenkan dengan teknik inversi sebesar $284.10^{3} / \mu 1$ darah. Rata-rata jumlah trombosit yang dihomogenkan dengan teknik angka delapan sebesar $276.10^{3} / \mu 1$ darah. Perbedaan yang signifikan jumlah trombosit yang dihomogenkan dengan teknik inversi dan teknik angka delapan ( $p$ value $=0,001)$. Disarankan pemeriksaan hitung jumlah trombosit dihomogenkan dengan teknikinversi agar didapatkan hasil yang akurat yang sesuai dengan kondisi pasien yang sesungguhnya,

\section{UCAPAN TERIMA KASIH}

Penulis mengucapkan terima kasih kepada Balai Besar Laboratorium Kesehatan yang telah memberi dukungan dan bantuan selama proses penelitian.

\section{DAFTAR PUSTAKA}

Decie, SJV, Lewis SM. 1991. Pratical Haematology; Eleventh edition. Logman Singapore Publisher Ltd: Singapore

Gandasoebrata, R. 2010. Penuntun Laboratorium Klinik. Dian Rakyat: Jakarta

Kathryn A.Booth, Antonio C. Wallance., Debbie t, Fitgenerald. 2008. Flebotomy For HealtH Care Personal. Second edition. McGrawHilL Higher Education: Amerika

Sudjana,.1986. Metode Statistika. Edisi ke-6.

Tarsito: Bandung
Tetty R, Riestina P, Wahyuni, Tantri. 2017.

Buku Panduan Praktis Hematologi

Dasar. Learning Center Indonesia: Jakarta

Tri, P.M. 2014. Cara Mudah Belajar Fisiologi Kedokteran. Nusa Medika: Yogyakarta 